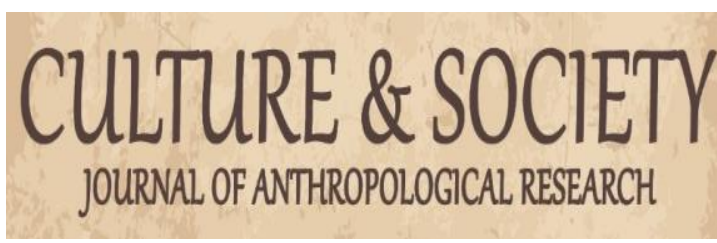

Culture \& Society: Journal of Anthropological Research

VOL. 2 NO. 1 SEPTEMBER 2020

http://culture.ppj.unp.ac.id

Email: culture@ppj.unp.ac.id

ISSN: 2686-343X (E-ISSN) 2686-3421 (P-ISSN)

DOI: https://doi.org/10.24036/csjar.v2i1.50

\title{
Jaringan Sosial Tanah Ombak dalam Mengembangkan Budaya Literasi
}

\author{
Anisaq Qastalani Sajidah ${ }^{1}$, Erda Fitriani ${ }^{2}$ \\ ${ }^{1,2}$ Universitas Negeri Padang \\ Email: anisaqastalani97@gmail.com, fitriani_cim@fis.unp.ac.id
}

\begin{abstract}
Abstrak
Latarbelakang penelitian ini adalah munculnya jaringan sosial Tanah Ombak untuk mengembangkan budaya literasi. Penelitian ini bertujuan untuk menjelaskan apa bentuk jaringan sosial Tanah Ombak dalam mengembangkan budaya literasi di Kampung Purus III, Kelurahan Purus, Kecamatan Padang Barat. Metode penelitian yang digunakan pendekatan kualitatif dengan tipe penelitian studi kasus. Pemilihan informan secara purposive sampling dengan jumlah 13 informan. Pengumpulan data dilakukan secara observasi partisipasi pasif, wawancara mendalam, dan dokumentasi. Analisis data dilakukan dengan teknik analisis interaktif Miles dan Huberman dengan cara reduksi data, penyajian data dan penarikan kesimpulan. Hasil penelitian menunjukan bahwa : A. Jaringan Sosial yang dilakukan Tanah Ombak diantaranya: 1) Jaringan Sosial Pertemanan, 2) Jaringan Sosial dengan Pihak Pemerintah Daerah, 3) Jaringan Sosial dengan Pihak LSM, 4)Jaringan Sosial dengan Pihak CSR Perusahaan, 5) Jaringan Melalui Media Sosial.

Kata kunci: Budaya Literasi, Jaringan Sosial, Tanah Ombak

\section{Abstract}

The background of this research is the emergence of Tanah Ombak social network to develop literacy culture. This study aims to explain what form the Tanah Ombak social network is in developing a literacy culture in Purus III Village, Purus Village, West Padang District. The research method used was a qualitative approach with a case study research type. Selection of informants by purposive sampling with a number of 13 informants. Data collection was carried out by means of passive participation observation, in-depth interviews, and documentation. Data analysis was performed using interactive analysis techniques Miles and Huberman by means of data reduction, data presentation and drawing conclusions. The results showed that: A. The Social Network that Tanah Ombak conducted included: 1) Social Network of Friends, 2) Social Networking with Local Government Parties, 3) Social Networking with NGOs, 4) Social Networking with Corporate CSR Parties, 5) Networking Through Social Media.
\end{abstract}

Keywords: Literacy Culture, Social Networks, Tanah Ombak

\begin{tabular}{|l|l|l} 
Received: July 30, 2020 & Revised: August 13, 2020 & Published: August 14, 2020
\end{tabular}




\section{Pendahuluan}

Literasi ialah sebagai keterampilan seseorang dalam mendengarkan, berbahasa, membaca, dan menulis dalam berkomunikasi dengan menggunakan cara yang berbeda sesuai dengan tujuannya. Keterampilan membaca dan menulis sangat dibutuhkan untuk menciptakan sikap kritis dan kreatif dalam berbagai aspek kehidupan yang membangun hubungan pertemanan serta sebagai upaya melestarikan budaya bangsa. Literasi berguna untuk mengembangkan sumber daya manusia yang berkualitas. Untuk menumbuhkan rasa ingin tahu terhadap pengetahuan bisa diwujudkan dengan kebiasaan membaca atau bisa disebut dengan budaya literasi. Hal ini membutuhkan waktu yang cukup lama agar dapat menciptakan pribadi yang berkarakter serta dapat menumbuhkan budi pekerti luhur, sehingga diperlukan kebiasaan membaca sejak dini. Kegiatan literasi bisa dilakukan dimanapun, baik di kelas maupun di luar kelas (Sari, Swastika Esti \& Pujiono, 2017). Literasi dapat diartikan sebagai kegiatan untuk membantu proses pembelajaran serta berguna untuk menambah wawasan, pembendaharaan kata, melatih menulis dan untuk menumbuhkan minat baca sejak dini (Dharma, 2016). Budaya Literasi sebagai upaya untuk menciptakan masyarakat yang cerdas. Pendidikan Literasi merupakan solusi untuk

mengantisipasi penyebaran Hoax yang ditengah berkembang pesat dalam masyarakat (Fernandes et al., 2019).

Program literasi yang sudah memiliki kemajuan dalam membangun karakter anak bangsa ialah Tanah Ombak, yang terletak di Kampung Purus III, Kelurahan Purus, Kecamatan Padang Barat. Diantara program literasi Tanah Ombak ialah membaca, menulis, teater, musik, melukis dan tarian. Kampung Purus III dulu disebut sebagai Gang Setan. Gang Setan merupakan Gang buntu yang panjangnya sekitar 50 Meter dari tepi jalan raya. Gang Setan tempatnya para perilaku kriminal dan semua hal negatif ada disana. Tanah Ombak sendiri bermula dari kenekatan Robby dan tiga temannya mendirikan taman bacaan di Gang Setan Tahun 2015. Niat keempat anak teater itu yakni tidak ingin anak-anak di Gang Setan menjadi perilaku kriminal seperti orang-orang yang ada disana. Rintangan sudah pasti didapat. Dua tahun Tanah Ombak berdiri, selama itu intimidasi datang tiada henti (Herawati, n.d.).

Tanah Ombak memiliki sejumlah program literasi, di dalam program tersebut ada sejumlah program yang sudah berhasil dan ada juga yang belum berhasil. Program literasi yang sudah berhasil diantaranya anak-anak di Kampung Purus III sudah banyak meraih sejumlah prestasi diantaranya pada tahun 2014 Tanah Ombak berhasil memenangkan penampilan terbaik pada festival teater anak-anak Nasional di Taman Ismail Marzuki, Jakarta. Pada tahun 2016 Tanah Ombak mampu meraih anugerah literasi Minangkabau, Komunitas terbaik I Sumatera Barat dan prestasi Teranyar, mereka menjadi juara I Regional Sumatera dalam Gramedia Reading Community Competition (GRCC) 2016 (Bempah, 2017). Dalam mencapai kesuksesan tersebut Tanah Ombak melakukannya dengan cara mengembangkan budaya literasi melalui jaringan-jaringan sosial yang terdapat aktor-aktor jaringan sosial yang berperan dalam proses perubahan (Harini, 2012).

Penelitian yang relevan yaitu penelitian Amelia Rahmi yang berjudul Pengenalan Literasi Media pada Anak Usia Sekolah Dasar. (Rahmi, 2013). Penelitian yang relevan lainnya dengan penelitian ini adalah penelitian yang dilakukan oleh Ahmad Solihin yang berjudul Optimalisasi Pengelolaan Taman Bacaan Masyarakat Al-Suroya dalam Meningkatkan Minat Membaca Literasi Islam. (Solihin, 2019). Penelitian yang relevan lainnya dengan penelitian ini adalah penelitian Atikah Anindyarini, Sumarwati, Budi Waluyo, Sri Hastuti, Yant Mujiyanto yang berjudul Strategi Menghidupkan Budaya Literasi melalui Dongeng. (Anindyarini et al., 2019). Berdasarkan studi relevan tersebut maka penelitian mengenai jaringan sosial pada lembaga literasi belum banyak diteliti oleh karena itu penelitian ini membahas topik Jaringan Sosial Tanah Ombak dalam Mengembangkan Budaya Literasi.

Jaringan sosial merupakan suatu jaringan tipe khusus dimana ikatan yang menghubungkan satu titik ketitik lain di dalamnya ialah hubungan sosial. Menurut J.A Barnes, jaringan sosial merupakan suatu pengelompokan yang terdiri dari tiga orang atau lebih yang masing-masing

Culture \& Society: Journal of Anthropological Research Vol. 2, No. 1, Th. 2020 
orang tersebut mempunyai identitas tersendiri dan masing-masing dihubungkan antara satu dengan yang lainnya melalui hubungan sosial yang ada, sehingga melalui hubungan-hubungan sosial tersebut mereka itu dapat dikelompokan sebagai suatu kesatuan sosial atau kelompok sosial. Jaringan sosial yang dilakukan Tanah Ombak dalam mengembangkan budaya literasi dibagi menjadi dua, yaitu jaringan total dan jaringan bagian. Pertama, jaringan total adalah keseluruhan jaringan yang dimiliki individu dan mencakup berbagai konteks atau bidang kehidupan dalam masyarakat.

\section{Metode Penelitian}

Jenis penelitian yang digunakan pendekatan kualitatif, karena permasalahan dalam penelitian ini bersifat kompleks, dinamis serta penuh makna, sehingga bertujuan untuk memahami keadaan sosial secara mendalam (Moleong, 2002). Penelitian ini hanya terfokus dalam melihat jaringan sosial Tanah Ombak dalam mengembangkan budaya literasi. Tipe penelitian yang digunakan studi kasus. Studi kasus ialah rancangan penelitian yang mengembangkan analisis mendalam terhadap suatu kasus. Kasus-kasus dibatasi oleh waktu dan aktivitas serta penelitian mengumpulkan informasi secara lengkap dengan memakai beragam prosedur pengumpulan data berdasarkan waktu yang telah ditentukan (W. Creswell, 2016). Tipe studi kasus yang digunakan tipe studi kasus intrinsik, studi kasus intrinsik menekankan pada pemahaman (Verstehen) mendalam tetapi tidak dimaksudkan untuk memahami fenomena umum yang bisa digeneralisasikan, namun lebih mementingkan kepentingan intrinsik serta tidak dimaksudkan untuk membentuk teori baru (Idrus, 2009).

Penelitian dilakukan di Kampung Purus III. Alasannya karena taman baca Tanah Ombak terletak di Kampung Purus III. Informan penelitian dipilih secara (purposive sampling), alasan peneliti menggunakan teknik ini karena peneliti telah memiliki pemetaan terhadap orang yang akan dijadikan informan. Informan penelitian dalam penelitian ini diantaranya: Informan dalam penelitian ini adalah (1) Pendiri sekaligus Pengurus Tanah Ombak, (2) Teman sekaligus Pendiri (3) Relawan Tanah Ombak, (4) LSM, (5) Pemerintah Daerah/ Kelurahan Purus, (6) Masyarakat dan, (7) Anak-anak yang aktif belajar di Tanah Ombak. Total informan penelitian ini mencapai 13 (Tiga Belas) orang informan, dengan rincian 1 ( Satu) Pendiri sekaligus Pengurus Tanah Ombak, 1 (Satu) Teman sekaligus Pendiri, 1(Satu) Relawan Tanah Ombak, 2 (Dua) LSM, 1 (Satu) Pemerintah Derah/ Kelurahan Purus, 3 (Tiga) Masyarakat dan, 4 (Empat) Anak-anak yang aktif belajar di Tanah Ombak.

Teknik pengumpulan data dilakukan pada natural setting (kondisi yang alamiah), sumber data primer, dan teknik pengumpulan data lebih banyak pada observasi berperan serta (partisipant observasion), wawancara mendalam (in depth interview) dan dokumentas (Sugiyono, 2017). Peneliti menggunakan teknik pengumpulan data observasi, wawancara dan dokumentasi dalam penelitian yang dilakukan. Observasi (pengamatan) yang digunakan dalam penelitian ini observasi partisipasi pasif. Dalam hal ini peneliti datang ke tempat kegiatan yang diamati, tetapi tidak ikut terlibat dalam kegiatan tersebut (Sugiyono, 2017). Dalam hal ini peneliti mengamati jaringan sosial Tanah Ombak dalam mengembangkan budaya literasi. Setelah melakukan observasi peneliti melakukan wawancara dengan subjek penelitian yaitu Pendiri sekaligus Pengurus Tanah Ombak, Teman Sekaligus Pendiri, Relawan Tanah Ombak, LSM, Pemerintah Daerah/Kelurahan Purus, Masyarakat dan Anak-anak yang aktif belajar di Tanah Ombak. Selain observasi dan wawancara, peneliti juga menggunakan berbagai dokumen dalam menjawab pertanyaan terarah. Studi dokumen merupakan pelengkap dari pengguna metode observasi dan wawancara dalam peneliti.

Analisis data merupakan suatu penyusunan data agar data tersebut dapat ditafsirkan. Menyusun data berarti mengelompokan dalam pola atau kategori sedang tafsiran atau interprestasi artinya memberikan makna pada analisa dalam menjelaskan pola atau kategori dalam mencari hubungan antar berbagai konsep (W. Creswell, 2016). Reduksi data merupakan proses pemilihan, pemusatan perhatian pada penyederhanaan, pengabstrakan dan transformasi data kasar yang muncul dilapangan. Pengabstrakan yang dimaksud dalam penelitian ini adalah

Culture \& Society: Journal of Anthropological Research Vol. 2, No. 1, Th. 2020 
membuat rangkuman (menajamkan, menggolongkan, mengarahkan serta membuang yang tidak perlu) proses penelitian mengenai pengamatan tentang jaringan sosial Tanah Ombak dalam mengembangkan budaya literasi. Penyajian data atau display data merupakan penyajian data secara sederhana yang dapat mempermudah dalam penarikan kesimpulan. Penyajian data secara sederhana yang dapat mempermudah dalam penarikan kesimpulan. Penyajian data ini diperlukan agar tidak menyimpang dari pokok permasalahan. Penarikan kesimpulan dilakukan untuk mengumpulkan data-data hasil wawancara dan observasi mengenai jaringan sosial Tanah Ombak dalam mengembangkan budaya literasi.

\section{Hasil dan Pembahasan}

\section{Hasil}

Tanah Ombak merupakan sebuah taman baca yang didirikan oleh komunitas di Kampung Purus III. Tanah Ombak memiliki sejumlah program yang sudah sukses. Kesuksesan yang dicapai Tanah Ombak melalui jaringan sosial yang dibentuk. Jaringan sosial merupakan suatu hubungan sosial yang sengaja dibentuk untuk menjaga kesatuan sosial atau keseimbangan hubungan individu dengan kelompok. Bentuk jaringan sosial Tanah Ombak dalam mengembangkan budaya literasi adalah sebagai berikut:

\section{Jaringan Sosial Pertemanan}

Teman merupakan kelekatan yang penuh afeksi antara dua orang atau lebih. Pertemanan mulai berlangsung pada saat hubungan seseorang semakin erat seperti, banyaknya persamaan yang ada, intensitas bertemu yang tinggi serta perbedaan yang ada digunakan untuk saling melengkapi akan meningkatkan hubungan pertemanan dengan persahabatan. Kegiatan di atas mampu menghadirkan manfaat positif saat kualitas persahabatan dijaga (Lestari, 2020). Awal berdirinya Tanah Ombak bermula ketika Bapak Suhendri selaku pengurus sekaligus pendiri tempat Sastra dan Teater Noktah bertemu dengan teman baiknya yang bernama Bapak Yusrizal KW. Pertemuan mereka memperbincangkan banyak hal dan salah satu mengenai tentang keadaan Sastra dan Teater Noktah yang dibina oleh Bapak Suhendri. Beliau menceritaka kepada Bapak Yusrizal KW teman baiknya itu, kalau keadaan Sastra dan Teater Noktah saat ini mulai redup dan ia ingin mengembangkan kegiatan tersebut menjadi sebuah kegiatan yang lebih dekat dengan masyarakat terutama anak-anak. Pemikiran Bapak Suhendri tersebut dilatarbelakangi karena perhatiannya terhadap anak-anak yang banyak berkeliaran di Kampung Purus III. Ketika mendengarkan cerita Bapak Suhendri dengan seksama, Bapak Yusrizal KW pun memberi arahan kepada teman lamanya itu untuk mengembangkan tempat Sastra dan Teater Noktah tersebut menjadi taman baca Tanah Ombak anak-anak atau lebih tepatnya lagi tempat yang memperkenalkan akan pentingnya literasi kepada masyarakat. Arahan Bapak Yusrizal KW diterima dengan sangat baik oleh Bapak Suhendri, karena sebelumnya ia tidak mengetahui lebih luas dengan istilah literasi.

\section{Jaringan Sosial dengan Pihak Pemerintah Daerah.}

Pemerintah Daerah merupakan penyelenggaraan urusan pemerintahan oleh Pemerintah Daerah dan Dewan Perwakilan Rakyat Daerah. Kewenangan pemerintahan wajib memiliki arti suatu urusan pemerintahan yang berkaitan dengan pelayanan dasar seperti pendidikan dasar, kesehatan, kebutuhan hidup minimal, prasarana lingkungan, dan lain lain. Sedangkan (Farid \& Antikowati \& Indrayati, 2017). Kegiatan yang dilakukan di taman baca Tanah Ombak mendapat dukungan dari berbagai pihak. Salah satunya Pemerintah Daerah. Pemerintah yang peneliti hubungi yaitu bagian Kelurahan Purus yang mengetahui adanya taman baca di Kampung Purus III tersebut melalui postingan Bapak Yusrizal KW maupun Bapak Suhendri di media sosial. Postingan yang di upload Bapak Suhendri lebih terfokus kepada kegiatan literasi, sedangkan Bapak Suhendri lebih suka memposting mengenai kegiatan apa saja yang dilakukan di Tanah Ombak, seperti berteater salah satunya. Bantuan yang diberikan Pemda biasanya berupa materil. Bantuan yang diterima oleh Tanah Ombak akan digunakan untuk perbaikan tempat membaca tersebut.

Culture \& Society: Journal of Anthropological Research Vol. 2, No. 1, Th. 2020 
Seperti memperbaiki lantai Tanah Ombak menjadi keramik dan digunakan untuk biaya anak-anak ketika ada kegiatan festival.

\section{Jaringan Sosial dengan Pihak LSM (Lembaga Swadaya Masyarakat)}

Lembaga Swadaya Masyarakat merupakan sebuah organisasi yang didirikan oleh perorangan ataupun sekelompok orang secara suka rela yang memberikan pelayanan kepada tanpa bertujuan untuk memperoleh keuntungan dari kegiatannya. LSM mempunyai fungsi strategis sebagai pelopor yang melayani perubahan social (Assadi et al., 2009). Hubungan sosial yang dimiliki oleh Tanah Ombak dengan beberapa LSM diantaranya: Ruwandu (Ruang Anak Dunia), Rumah Anak Soleh dan STBA (Sekolah Tinggi Bahasa Asing). Hubungan sosial yang dimilki oleh Tanah Ombak dengan LSM tersebut berupa hubungan kerjasama dalam mencapai tujuan bersama.

\section{Jaringan Sosial dengan Pihak CSR Perusahaan}

Tanah Ombak menerima bantuan dari sejumlah donatur yang tertarik dengan kegiatan literasi. Bantuan yang diberikan berupa materil dan non materil (buku, alat-alat tulis dan lain sebagainya). Bantuan berupa materil digunakan untuk membeli perlengkapan di taman baca Tanah Ombak tersebut, terutama buku dan peralatan menulis dan perlengakapan lainnya yang dirasa masinh kurang. Diantara donatur tersebut ialah CSR Perusahaan diantaranya: PLN, PT. Coca Cola, Semen Padang, Kereta Api dan Askrindo. Bantuan yang diterima Tanah Ombak melalui proposal yang diajukan. Proposal yang diajukan tersebut karena diusulkan oleh pihak CSR Perusahaan yang datang ke Tanah Ombak dan menyarankan untuk mengajukan proposal ke perusahaan mereka.

\section{Jaringan Melalui Media Sosial}

Tanah Ombak memiliki sejumlah kegiatan yang dilakukan untuk anak-anak yang tinggal di Kampung Purus III, Kelurahan Purus. Kegiatan yang dilakukan anak-anak di taman baca Tanah Ombak tersebut biasanya di posting lewat media sosial oleh relawan maupun pendiri sekaligus pengurus Tanah Ombak.

Dari hasil temuan peneliti di atas dapat dianalisis dengan menggunakan teori Jaringan Sosial yang dikembangkan oleh J.A Barnes. Teori ini dipilih dengan alasan bahwa budaya literasi yang dikembangkan Tanah Ombak merupakan sebuah jaringan sosial. Jaringan sosial sebagai suatu pengelompokkan yang terdiri atas sejumlah orang, paling sedikit terdiri atas tiga orang yang masing-masing mempunyai identitas tersendiri dan masing-masing dihubungkan antara satu dengan yang lainnya melalui hubungan-hubungan sosial yang ada, sehingga melalui hubungan sosial tersebut mereka dapat dikelompokkan sebagai suatu kesatuan sosial.

Bentuk jaringan sosial yang dilakukan Tanah Ombak ialah melalui hubungan pertemanan, Pemerintah Daerah, Lembaga Swadaya Masyarakat, CSR Perusahaan dan media sosial. Dalam hubungan sosial yang dimiliki masing-masing mempunyai identitas tersendiri dan dihubungkan satu sama lain, sehingga dapat dikelompokkan sebagai kesatuan sosial. Jaringan sosial terbentuk dalam masyarakat karena pada dasarnya manusia tidak dapat berhubungan dengan semua manusia yang ada, hubungan selalu terbatas pada sejumlah orang tertentu. Setiap orang belajar dari pengalamannya untuk masing-masing memilih dan mengembangkan hubungan-hubungan sosial yang terbatas jumlahnya dibandingkan dengan jumlah rangkaian hubungan sosial yang tersedia, disesuaikan dengan kebutuhan-kebutuhan yang ada pada individu yang bersangkutan sehingga dalam usaha peningkatan taraf hidup juga tidak menggunakan semua hubungan sosial yang dimilikinya.

Jaringan sosial yang dilakukan Tanah Ombak dalam mengembangkan budaya literasi dibagi menjadi dua, yaitu jaringan total dan jaringan bagian. Pertama, jaringan total adalah keseluruhan jaringan yang dimiliki individu dan mencakup berbagai konteks atau bidang kehidupan dalam masyarakat. Tanah Ombak sengaja didirikan oleh Bapak Suhendri dan teman baiknya Bapak Yusrizal KW dengan tujuan untuk membuat kehidupan masyarakat yang berada di Kampung

Culture \& Society: Journal of Anthropological Research Vol. 2, No. 1, Th. 2020 
Purus III terutama anak-anak menjadi lebih baik lagi. Hal ini dilakukan supaya masyarakat disana tidak jauh ketinggalan dengan masyarakat lainnya terutama dalam segi pengetahuan. Melalui hubungan pertemanan yang dimiliki tersebut membuat Bapak Suhendri dan Bapak Yusrizal KW berupaya untuk membuat Tanah Ombak semakin dikenal banyak orang. Hal tersebut dilakukan dengan cara memposting selurh kegiatan yang dilakukan di Tanah Ombak. Melalui postingan tersebut Tanah Ombak akhirnya dikenal banyak pihak dan berpartisipasi sebagai donatur atau sebagai relawan di Tanah Ombak. Diantara pihak tersebut ialah Pemerintah Daerah, Lembaga Swadaya Masyarakat dan CSR Perusahaan. Kedua, Jaringan Bagian adalah jaringan yang dimiliki oleh individu terbatas pada bidang kehidupan tertentu, misalnya jaringan politik, jaringan keagamaan, jaringan kekerabatan, dan sebagainya. Jaringan politik yang dimiliki Tanah Ombak ialah melalui hubungan pertemanan Bapak Suhendri dengan Bapak Yusrizal KW. Bapak Yusrizal KW memiliki jaringan sosial yang sangat luas, memiliki teman-teman yang hebat. Melalui petemanan tersebut Bapak Yusrizal KW mempublikasikan Tanah Ombak lewat postingannya tentang taman baca masyarakat tersebut.

Jaringan-jaringan hubungan yang terbentuk didalam masyarakat menjadi sedemikian penting bagi masyarakat tersebut karena di dunia ini tidak ada manusia yang tidak menjadi bagian dari jaringan-jaringan hubungan sosial dengan manusia lainnya didalam masyarakatnya. Manusia di bumi ini selalu membina hubungan sosial dengan manusia lain di manapun ia tinggal dan hidup, sebab manusia pada dasarnya tidak dapat dan tidak sanggup hidup sendiri. Sebuah masyarakat dapat dipandang sebagai jaringan hubungan sosial antar individu yang sangat kompleks. Seorang individu hanya menjadi anggota dari jaringan-jaringan sosial tertentu dan tidak menjadi anggota jaringan-jaringan yang lain. Hal ini disebabkan oleh ketidak sanggupan manusia untuk berhubungan dengan semua manusia yang ada hubungannya selalu terbatas pada sejumlah orang tertentu. Teori yang dikembangkan oleh J.A Barnes tentang Jaringan Sosial dapat terlihat dari Jaringan Sosial Tanah Ombak dalam Mengembangkan Budaya Literasi. Jaringan sosial merupakan suatu hubungan sosial yang sengaja dibuat sebagai kesatuan sosial. Untuk membentuk hubungan sosial tersebut Tanah Ombak harus membentuk jaringan sosial dalam mengembangkan budaya literasi.

\section{Pembahasan}

Penelitian yang relevan dengan penelitian ini adalah penelitian yang dilakukan oleh Amelia Rahmi yang berjudul Pengenalan Literasi Media pada Anak Usia Sekolah Dasar. Temuannya adalah kehadiran media massa telah memberi banyak perubahan dalam kehidupan bermasyarakat, berbangsa dan cara kita beragama atau mengamalkan ajaran agama yang kita anut. Seluruh lapisan masyarakat juga terkena perubahan, termasuk anak usia sekolah dasar. Oleh karena itu guru SD dapat menyisipkan materi literasi media saat mengajar di kelas dengan model penayangan audio visual film kartun yang banyak digemari anak-anak, dan dialog kepada murid setelah menyaksikan tayangan tersebut.

Penelitian yang relevan lainnya dengan penelitian ini adalah penelitian yang dilakukan oleh Ahmad Solihin yang berjudul Optimalisasi Pengelolaan Taman Bacaan Masyarakat Al-Suroya dalam Meningkatkan Minat Membaca Literasi Islam. Temuannya adalah Taman Bacaan Masyarakat (TBM) yang ada di tengah-tengah masyarakat belum dapat dimanfaatkan oleh masyarakat secara optimal, tidak sedikit TBM yang ada hanya ingin diakui oleh pemerintah sehingga tujuan dan fungsi TBM belum dapat dirasakan oleh masyarakat. Hal ini disebabkan oleh sistem pengelolaan TBM yang belum tertata dengan baik, pengurus TBM tersebut hanya membuat proposal dan kegiatan TBM, membuat kepengurusan tapi kurang maksimal menjalankan tugasnya dan hanya memajang bukubuku yang mereka punya di rak-rak kayu. Permasalahan ini ditambah dengan bentuk pengelolaan terhadap sarana dan prasarana yang belum tertata dengan rapi.

Penelitian yang relevan lainnya dengan penelitian ini adalah penelitian Atikah Anindyarini, Sumarwati, Budi Waluyo, Sri Hastuti, Yant Mujiyanto yang berjudul Strategi Menghidupkan Budaya Literasi melalui Dongeng. Temuannya adalah upaya yang bisa dilakukan untuk

Culture \& Society: Journal of Anthropological Research Vol. 2, No. 1, Th. 2020 
meningkatkan literasi anak tidak hanya terbatas pada menumbuhkan minat baca anak, tetapi juga menumbuhkan minat anak untuk menulis. Dengan seringnya anak membaca dan menulis, kemampuan baca dan menulis anak akan semakin berkembang. Orangtua dan sekolah bisa melatih anak untuk menuliskan kembali buku apa yang telah dibaca serta melatih anak untuk menuliskan kembali pengalaman anak yang paling menarik.

Berdasarkan studi relevan tersebut maka penelitian ini lebih menekankan pada Jaringan Sosial Tanah Ombak dalam Mengembangkan Budaya Literasi. Peneliti tertarik untuk melakukan penelitian tentang jaringan sosial Tanah Ombak karena untuk mencapai kesuksesan yang diperoleh Tanah Ombak saat ini harus menciptakan hubungan-hubungan sosial agar terwujud semua keinginannya untuk mengembangkan Tanah Ombak sebagai tempat yang memperkenalkan literasi lebih luas lagi.

\section{Kesimpulan}

Tanah Ombak merupakan suatu taman baca yang dibuat oleh sebuah komunitas. Tanah Ombak memiliki sejumlah program yang telah sukses. Dalam mencapai kesuksesan tersebut Tanah Ombak membentuk jaringan sosial dalam mengembangkan budaya literasi. Jaringan sosial merupakan suatu hubungan sosial yang sengaja dibentuk untuk menciptakan kesatuan sosial.

Jaringan sosial Tanah Ombak menurut J.A Barnes terbagi dua, yaitu jaringan sosial total dan jaringan sosial bagian. Tanah Ombak sengaja didirikan oleh Bapak Suhendri dan teman baiknya Bapak Yusrizal KW dengan tujuan untuk membuat kehidupan masyarakat yang berada di Kampung Purus III terutama anak-anak menjadi lebih baik lagi. Hal ini dilakukan supaya masyarakat disana tidak jauh ketinggalan dengan masyarakat lainnya terutama dalam segi pengetahuan. Melalui hubungan pertemanan yang dimiliki tersebut membuat Bapak Suhendri dan Bapak Yusrizal KW berupaya untuk membuat Tanah Ombak semakin dikenal banyak orang. Hal tersebut dilakukan dengan cara memposting seluruh kegiatan yang dilakukan di Tanah Ombak. Melalui postingan tersebut Tanah Ombak akhirnya dikenal banyak pihak dan berpartisipasi sebagai donatur atau sebagai relawan di Tanah Ombak. Diantara pihak tersebut ialah Pemerintah Daerah, Lembaga Swadaya Masyarakat dan CSR Perusahaan.

Kedua, Jaringan Bagian adalah jaringan yang dimiliki oleh individu terbatas pada bidang kehidupan tertentu, misalnya jaringan politik, jaringan keagamaan, jaringan kekerabatan, dan sebagainya. Jaringan politik yang dimiliki Tanah Ombak ialah melalui hubungan pertemanan Bapak Suhendri dengan Bapak Yusrizal KW. Bapak Yusrizal KW memiliki jaringan sosial yang sangat luas, memiliki teman-teman yang hebat. Melalui petemanan tersebut Bapak Yusrizal KW mempublikasikan Tanah Ombak lewat postingannya tentang taman baca masyarakat tersebut.

\section{Daftar Pustaka}

Anindyarini Atikah, Sumarwati., Waluyo Budi., Hastuti Sri \& Mujiyanto Yant. (2019). Strategi Menghidupkan Budaya Literasi Melalui Dongeng. Senadimas Unisri, September, 253-258.

Assadi Husain., Hadi Darmawan, Arya \& Soeryo Adiwibowo. (2009). Independensi Lembaga Swadaya Masyarakat (LSM) di Tengah Kepentingan Donor. Sodality: Jurnal Sosiologi Pedesaan, 3(2), 231-258. https://doi.org/10.22500/sodality.v3i2.5864

Bempah Triyadi, Ramdhan. (2017). Tanah Ombak Terbitkan Asa Anak-anak di Pesisir Pantai Padang. https://amp.compas.com/regional/.

Dharma Satria. (2016). Transformasi Surabaya sebagai Kota Literasi. Surabaya:Unesa University Press.

Farid Mifta., Antikowati \& Indrayati Rosita. (2017). Kewenangan Pemerintah Daerah dan Partisipasi Masyarakat dalam Pengelolaan Potensi Daerah. E-Journal Lentera Hukum, 4(2), 71-84. https://doi.org/10.19184/ejlh.v4i2.5128

Fernandes Reno., Putra Eka, Vidya \& Muspita Rila. (2019). Optimalisasi Institusi Pendidikan sebagai Upaya Pengendalian Hoax. ABDI: Jurnal Pengabdian dan Pemberdayaan Masyarakat,

Culture \& Society: Journal of Anthropological Research Vol. 2, No. 1, Th. 2020 
1(1), 16-20. https://doi.org/doi: https://doi.org/10.24036/abdi/vol1-iss1/2 Optimalisasi. Harini Dwi, Novi. (2012). Pengaruh Jaringan Sosial pada Transformasi Masyarakat Nelayan. Jurnal Komunitas, 4(2), 178-190.

Herawati Lilik. Budaya Literasi Media dalam Meningkatkan Daya Baca Mahasiswa IAIN Cirebon. 294309.

Idrus Muhammad. (2009). Metode Penelitian Ilmu Sosial. Yogyakarta: Erlangga.

Lestari Made, Diah. (2020). Persahabatan: Makna dan kontribusinya bagi Kebahagiaan dan Kesehatan Lansia. Jurnal Psikologi Ulayat, 4(1), 59-82. https://doi.org/10.24854/jpu61

Moleong L.J . (2002). Metode Penelitian Kualitatif. Bandung: Rosdakarya.

Rahmi Amelia. (2013). Pengenalan Literasi Media pada Anak Usia Sekolah Dasar. Sawwa: Jurnal Studi Gender, 8(2), 261-276. https://doi.org/10.21580/sa.v8i2.656

Sari Swastika, Esti \& Pujiono Setyawan. (2017). Budaya Literasi dikalangan Mahasiswa FBS UNY. Litera, 16(1), 105-113.

Solihin Ahmad. (2019). Optimalisasi Pengelolaan Taman Bacaan Masyarakat AL-Suroya dalam Meningkatkan Minat Membaca Literasi Islam. Institut Agama Islam Negeri Metro.

Sugiyono. (2017). Metode Penelitian Kualitatif dan Kuantitatif dan R\&D. Bandung: Alfabeta.

W. Creswell, J. (2016). Pendekatan Metode Kualitatif, Kuantitatifdan Campuran. Yogyakarta: Pustaka Pelajar. 